\title{
Subacute combined degeneration of spinal cord - the only manifestation in an otherwise "normal" vitamin B12 deficient patient.
}

Nritya Trivedi ${ }^{1}$ and Darshankumar Raval ${ }^{1}$

${ }^{1}$ Medical College Baroda

December 22, 2021

\begin{abstract}
Sub acute combined degeneration (SACD) is a myelopathy associated with vitamin B12 deficiency. Vitamin B12 deficiency may present with neurological and/or hematological features - neurological features commonly presenting at a later stage than hematological changes. Our case is an unusual presentation of SACD without anemia
\end{abstract}

\section{Hosted file}

main document and title page.docx available at https://authorea.com/users/452308/articles/ 550404-subacute-combined-degeneration-of-spinal-cord-the-only-manifestation-in-an-

otherwise-normal-vitamin-b12-deficient-patient 